\title{
PRZESZŁOŚĆ CZY PRZYSZŁOŚĆ - DYLEMATY ZWIĄZANE Z ZABYTKAMI W DOBIE POSTKOLONIALIZMU
}

\author{
JAKUB LEWICKI ${ }^{1}$ \\ (Uniwersytet Kardynała Stefana Wyszyńskiego w Warszawie)
}

Słowa kluczowe: zabytki, rekonstrukcja, dziedzictwo kulturowe, PRL

Key words: monuments, reconstruction, cultural heritage, Poland under communism

\begin{abstract}
Abstrakt: Jakub Lewicki. PRZESZŁOŚĆ CZY PRZYSZŁOŚĆ - DYLEMATY ZWIĄZANE Z ZABYTKAMI W DOBIE POSTKOLONIALIZMU. „PORÓWNANIA” 17, 2015. T. XVII. S. 91-104. ISSN 1733-165X. W pracy porównano stosunek do dziedzictwa kulturowego i do zabytków w latach PRL (1944-89) i po 1989 roku. Dominowały wówczas trzy odmienne sposoby postępowania ze zniszczonymi zabytkami - profesjonalna konserwacja, która utrwalała stan zastany. Inną metodą były rekonstrukcje i odbudowy, które podejmowano nawet mimo upływu kilkudziesięciu lat od zniszczenia zabytku oraz stylizacje historyczne, w wyniku których wznoszono budynki będące swobodnym naśladownictwem dawnej architektury. Trzecią tendencją było wznoszenie budowli o nowoczesnych formach, które powstawały $\mathrm{w}$ miejscu zniszczonych zabytków lub w ich sąsiedztwie. W pracy szczegółowo przeanalizowano stosunek do przeszłości na przykładzie zabytków w czasach PRL i po 1989 roku, którego przejawem były rekonstrukcje, odbudowy i stylizacje historyczne. Uznano, że lata po 1989 roku stanowiły kontynuację epoki poprzedniej. Nadal kontynuowano wszystkie zjawiska z poprzedniego okresu PRL - liczne swobodne rekonstrukcje i odbudowy zabytków. Wiele z nich było swobodnymi stylizacjami historycznymi, a odtwarzane zabytki były "piękniejsze niż kiedykolwiek”. W czasach PRL towarzyszyła temu refleksja teoretyczna z wysuwanymi nowymi argumentami i spostrzeżeniami, a ostatnie lata nie posługiwały się nowymi tezami i uzasadnieniami. Obecną sytuację określono jako "długie trwanie" wypracowanych metod i sposobów działania w dziedzinie ochrony zabytków, które nadal są stosowane w nowej rzeczywistości społecznej i w zmienionych warunkach ustrojowych. Nowym zjawiskiem z ostatnich lat była pełna akceptacja wielonarodowego dziedzictwa i szereg działań na rzecz jego ochrony i konserwacji. Okres po upadku PRL przy-
\end{abstract}

\footnotetext{
${ }^{1}$ Correspondence Address: jakublewicki@poczta.onet.pl
} 
niósł także nowe wyzwania - najważniejszym był zmiana użytkowników wielu budowli, a w konsekwencji ich opuszczenie i konieczność znalezienia nowej funkcji. Duża liczba dawnych fabryk, młynów, magazynów, budowli przemysłowych i kolejowych została zrujnowana i rozebrana, a tylko nieliczne zabytkowe budowle zostały adaptowane. Innym wielkim wyzwaniem była globalizacja i urynkowienie, które objęło także zabytki. Było to zupełnie nowe zjawisko, które dziś stało się najważniejszym czynnikiem kształtującym stosunek do zabytków.

Abstract: Jakub Lewicki. THE PAST OR THE FUTURE - DILEMMAS WITH MONUMENTS IN THE TIMES OF POSTCOLONIALISM. "PORÓWNANIA" 17, 2015. Vol. XVII. P. 91-104. ISSN 1733-165X. The article presents a comparison of the attitude towards cultural heritage and monuments in Poland under communism (1944-89) and after 1989. Three different ways of handling destroyed monuments prevailed. Firstly, there was professional conservation, which preserved the status quo or reconstructions and rebuilding, which were carried out even tens of years after the destruction of the building. Also, there were historical stylisations the result of which were buildings built based on casual imitations of former architecture. The third tendency was to erect new buildings of modern form in place of the old dilapidated ones or near them. The article includes a detailed analysis of the attitude towards the past on the basis of monuments in Poland under communism and after 1989 which can be observed in the reconstructions, rebuilding and historical stylisations. It has been assumed that in the years after 1989 the tendency of the former era was continued. All phenomena from the times of communism were maintained including numerous reconstructions and rebuildings. Many of them were casual historical stylisations whereas the rebuilt buildings were "more beautiful than ever". In the times of communism it was accompanied by a theoretical reflection with new arguments and observations, whereas the last years did not witness new theses or arguments. The situation was defined as "long-time continuance" of the developed methods and ways of acting in the area of monument maintenance which are still used in the new social reality and different political system. A new phenomenon which has surfaced in the recent years is the full acceptance of multinational heritage and a number of actions towards its maintenance and conservation. The times after the fall of communism also brought new challenges, the most important of which was the change of the users of many buildings which lead to its abandoning and a necessity to find a new function for them. A great number of old factories, mills, warehouses, industrial and railway buildings were ruined and pulled down. Only some historical buildings were adapted to new functions. Globalisation and adapting to the market were other great challenges which also influenced the monuments. It was a wholly new phenomenon which has become the most important factor shaping the attitude towards monuments at present.

Lata po 1989 roku były okresem dużych zmian ustrojowych, ekonomicznych i kulturowych. W okresie tym nastąpiło przewartościowanie stosunku do teraźniejszości i przeszłości. Zmienił się także stosunek do całego dziedzictwa kulturowego i do zabytków architektury. Dominowały wówczas trzy odmienne sposoby postępowania ze zniszczonymi zabytkami. Obok ich profesjonalnej konserwacji, 
która utrwalała stan zastany, nadal je rekonstruowano i odbudowywano, mimo upływu kilkudziesięciu lat od ich zniszczenia. Zbliżonym sposobem postępowania były stylizacje historyczne, w wyniku których wznoszono budynki będące swobodnym naśladownictwem dawnej architektury. Odmienną tendencją było wznoszenie budowli o nowoczesnych formach, które powstawały w miejscu zniszczonych zabytków lub $\mathrm{w}$ ich sąsiedztwie. Te odmienne sposoby postępowania ukazują jeden z często dyskutowanych wówczas problemów - czy odtwarzać nieistniejącą rzeczywistość czy patrzeć w przyszłość, a nowe budowle mają być świadectwem epoki modernizacji i nowoczesności. W okresie tym dokonano też nowych podsumowań i oceny działań na rzecz ochrony i konserwacji zabytków w PRL (lata 1945-89). Już w połowie lat 90. XX wieku dokonali tego wybitni polscy historycy sztuki: Adam Miłobędzki, Andrzej Tomaszewski i Teresa Jakimowicz (Miłobędzki 1994: 131-141; Miłobędzki 1995: 22-25; Miłobędzki 1997a: 160-165; Miłobędzki 1997b: 97-101; Miłobędzki 2003: 19-22; Tomaszewski 1995; Jakimowicz 1994: 421-428). Ocena była bardzo krytyczna, a kontrowersyjne dla niektórych podsumowania, będące próbą odmiennego spojrzenia na ochronę zabytków w PRL, są jednymi z najbardziej wnikliwych opracowań na ten temat, jakie ukazały się $\mathrm{w}$ ostatnich latach. W pracach tych analizowano jeden $\mathrm{z}$ najważniejszych zagadnień związanych z polską ochroną zabytków, jakim jest problem rekonstrukcji, jako przejaw utopijnego powrotu do przeszłości. Rekonstrukcja i odbudowa były i są postrzegane jako jedno z najważniejszych zjawisk związanych z ochroną i konserwacją zabytków, które prezentują stosunek do przeszłości i do przyszłości.

\section{Rekonstrukcja zabytków i stylizacja historyczna nowych budowli}

Rekonstrukcja, jako świadomy zabieg konserwatorski istniała zawsze, bo już od początków istnienia ochrony zabytków (Nerdinger 2010; Falser 2010: 205-218). Także w Polsce często stosowano ją w XIX wieku, najpierw, jako przejaw tzw. romantycznych restauracji, potem jako element naukowego podejścia do zabytków (Frycz 1975: 35-261; Arszyński 2007: 95-230). Szczególnie chętnie rekonstruowano zabytki po 1945 roku. Nowe znaczenie pojęcia rekonstrukcji i odbudowy sformułował Jan Zachwatowicz, który podkreślił jej rolę dla przywrócenia zniszczonej historycznej zabudowy i zwracał na konieczność odtwarzania utraconych podczas wojny zabytków (Zachwatowicz 1965: 49-68). Pisał:

Nie mogąc zgodzić się na wydarcie nam pomników kultury, będziemy je rekonstruowali, będziemy je odbudowywali od fundamentów, aby przekazać pokoleniom, jeżeli 
nie autentyczną, to przynajmniej dokładną formę tych pomników, żywą w naszej pamięci, dostępną w materiałach. (...) Poczucie odpowiedzialności wobec przyszłych pokoleń domaga się odbudowy tego, co nam zniszczono, odbudowy pełnej i świadomego popełniania tragizmu fałszu konserwatorskiego (Zachwatowicz 1946: 48).

Wiele lat później $\mathrm{w}$ jednym $\mathrm{z}$ pierwszych podsumowań tego okresu podkreślano, że celem powojennej odbudowy było "odtworzenie zniszczonego obiektu”, a za modelową odbudowę uznano metodę chronienia jak największej liczby autentycznych elementów, rekonstrukcje brakujących i nadanie całości nowej funkcji, zgodnej z nowymi potrzebami i współgrającej z dawnym charakterem zabudowy (Rymaszewski 1986: 14). Było to jednak postępowanie bliskie ideałowi, w rzeczywistości bowiem wykonywano liczne swobodne rekonstrukcje, które stały się chętnie stosowaną metodą postępowania, a w odbudowywanych miastach powstawały nowe "doskonalsze" i "poprawione" zabytki, które były "piękniejsze niż kiedykolwiek" (Miłobędzki 2003: 23). Wiązało się to z ideą poprawiania zabytków, które miały być większe, mieć staranniej opracowane elewacje i odznaczać się wyższą klasą artystyczną. W poprawionej wersji odbudowano nie tylko zabudowę Starego Miasta w Warszawie, ale i klasycystyczne budynki przy Placu Bankowym i gmachy przy Krakowskim Przedmieściu. Modelowym przykładem podobnego postępowania była odbudowa warszawskiego pałacu Staszica mieszczącego prestiżowe naukowe instytucje i stanowiącego tło dla powszechnie wówczas reprodukowanego pomnika Mikołaja Kopernika odlanego przez Thordvaldsena. Autor projektu odbudowy i Konserwator Miasta Warszawy profesor architekt Piotr Biegański nie tylko poprawił proporcje elewacji i zmienił szczegóły dekoracji rzeźbiarskiej budynku, ale w efekcie stworzył dzieło będące wyobrażeniem wyidealizowanych proporcji epoki klasycyzmu, a zagadnienie poprawienia architektury budynku w ówczesnej literaturze prezentowano jako coś oczywistego i niezbędnego (Lalewicz 1932: 34-58; Biegański 1951: 172-5). Podobne metody poprawiania zabytków i nowe kształtowanie ich detalu stosowano także $w$ innych miastach. To utopijne widzenie przeszłości wzmocnione ideologią PRL legło u podstaw kolejnych wielkich rekonstrukcji, jakie podejmowano po 1989 roku. Pierwszą najbardziej znaną realizacją z tego cyklu była warszawska siedziba kilku banków przy Placu Teatralnym nazywana ratuszem albo pałacem Jabłonowskich (Fot. 1), która składa się tylko z odtworzonej w gazobetonie "historycznej” fasady oraz zupełnie z nią nie związanego układu wnętrz i kondygnacji ze stropami przebiegającymi $\mathrm{w}$ połowie okien pseudo zabytkowej elewacji. $\mathrm{W}$ centrum Warszawy powstał monumentalny gmach, który doskonale eksponowany stał się przedmiotem licznych dyskusji i krytyki. Jednak potem wznoszono kolejne budowle powstałe podług analogicznej metody postępowania. Najbardziej znanym gdańskim odpowiednikiem była odbudowa jednej z pierzei ulicy Stągiewnej. Jej elewacje odtworzone w historycznych formach zostały doklejone do żelbetonowej struktury wypełniającej 
Fot. 1. Warszawa, nowa zabudowa przy Placu Teatralnym nazywana ratuszem albo pałacem Jabtonowskich, stan w 2010 roku. Fot. J. Lewicki
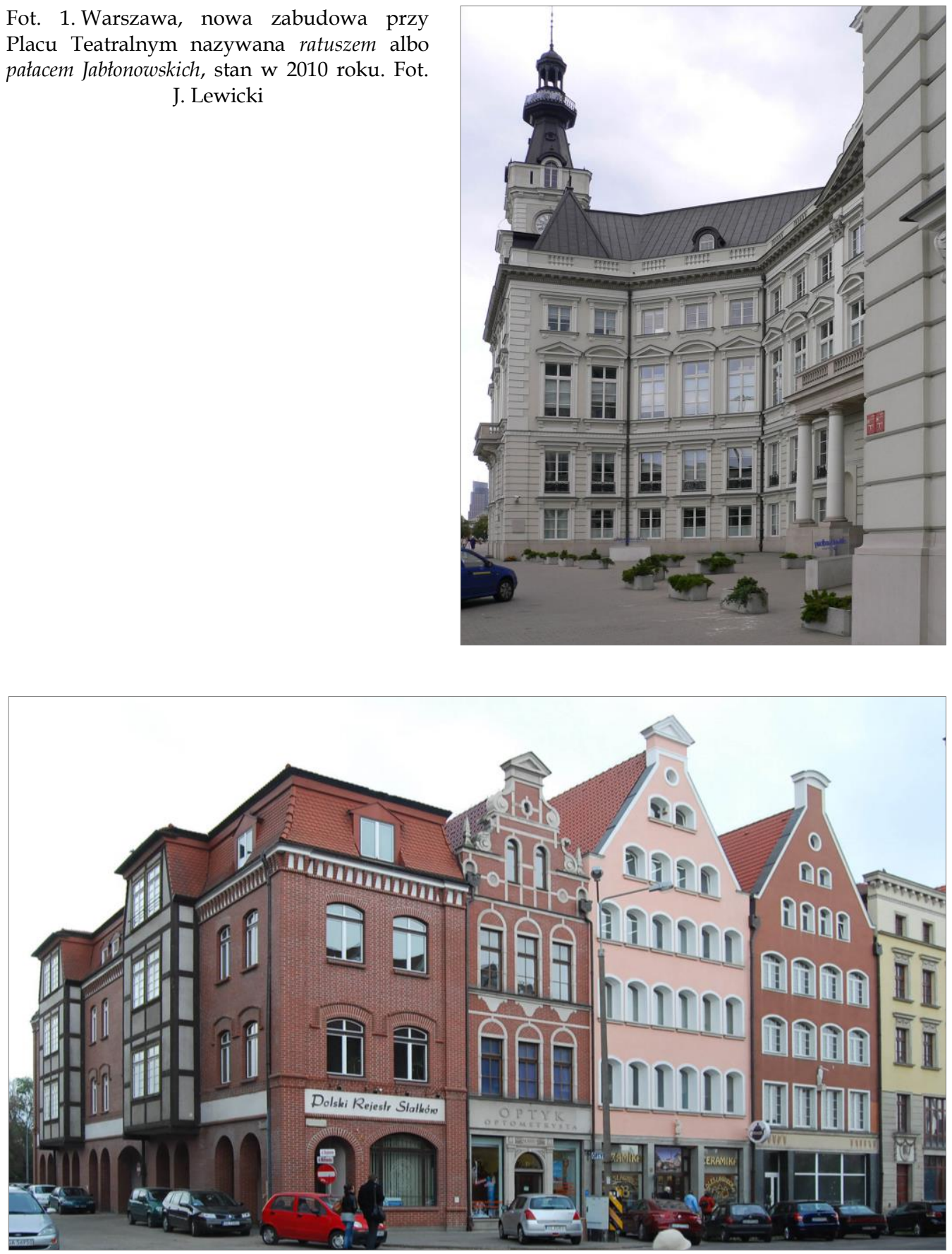

Fot. 2. Gdańsk, nowa zabudowa ulicy Stągiewnej naśladująca tradycyjną architekturę, stan w 2010 roku. Fot. J. Lewicki 


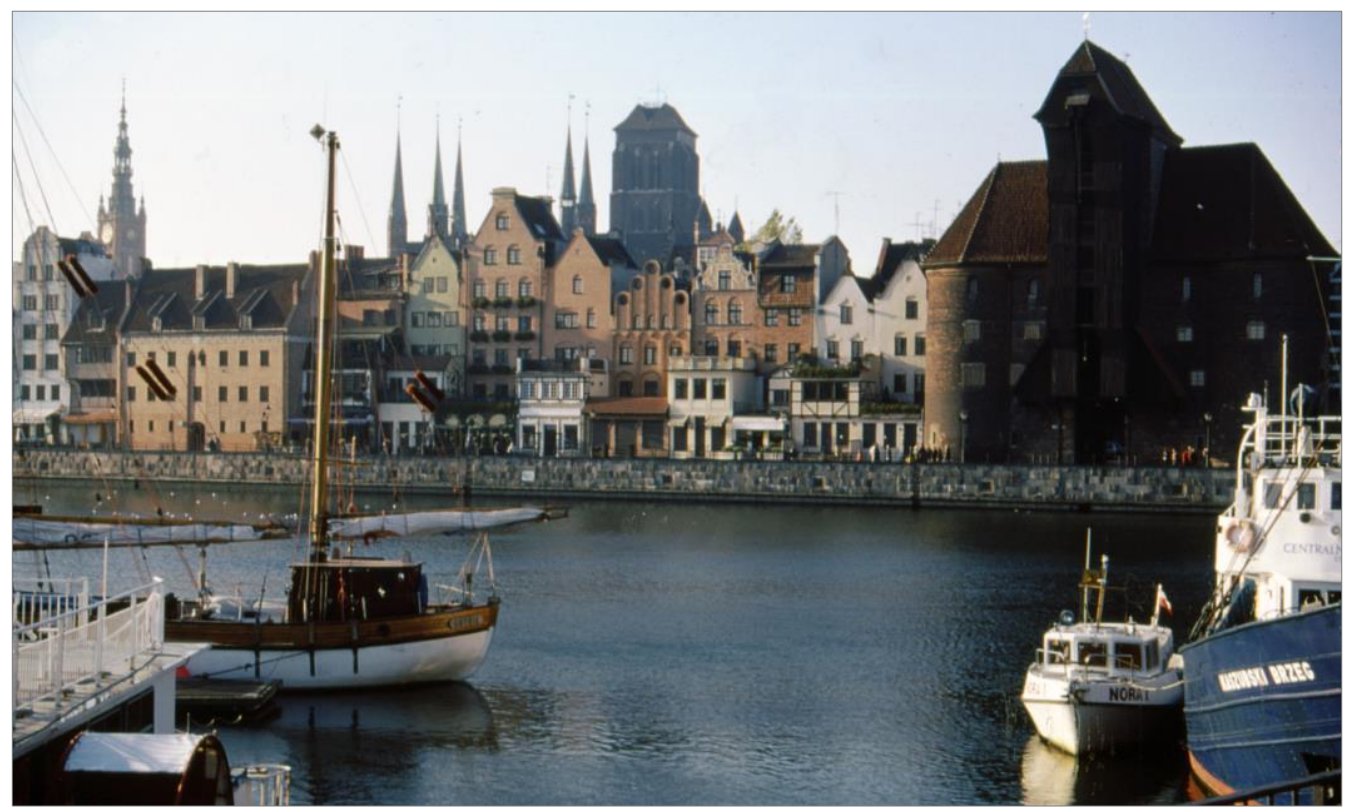

Fot. 3. Gdańsk, nowa zabudowa nad Motławą, stan w 2001 roku. Fot. J. Lewicki

całą zabudowę kwartału. Fasady ozdobiły projektowane komputerowo i wykonane z gazobetonu naśladujące zabytki „historyczne” detale. Współczesne wykonawstwo jeszcze bardziej podkreśliło karykaturalność tej rekonstrukcji wykonanej przez architekta i konserwatora-projektanta. Zespół zabudowy przy ulicy Stągiewnej (Fot. 2) także był przedmiotem dyskusji i krytyki. W późniejszych latach proces łączenia żelbetonowych budowli z "historycznym odtwarzaniem” elewacji nasilił się. Podobne budowle postawały nie tylko w Gdańsku - kamienice nad Motławą (Fot. 3), pojedyncze kamienice na terenie gdańskiego Głównego Miasta i Szczecina - dzielnica Podzamcze czy ostatnio w Poznaniu - Zamek Przemysła (Fot. 4). Jest to najbardziej monumentalna realizacja $\mathrm{z}$ tej serii, w wyniku której powstał ogromny gmach, której nieporadna bryła jest efektem wyobraźni i niewiedzy współczesnego projektanta i nie ma żadnych podstaw w źródłach ikonograficznych jak i w znanych zapisanych dokumentach. Także i inne rekonstruowane zabytki wznoszone w centrach miast stały się przedmiotem dyskusji i krytyki. Nawet wrocławska kamienica „Pod Złotym Psem” wzniesiona przy rynku staromiejskim przy użyciu tradycyjnych metod budowlanych razi swoją sztywnością i sztucznością, mimo oparcia się na dokładnej ikonografii i zastosowaniu tradycyjnej technologii. Prace te wykonywano niezależnie od ochrony zachowanych oryginalnych zabytków, które zniszczone i niedoinwestowane dogorywały w pobliżu tych nowo wznoszonych budowli. Nowy ustrój nie tylko nie zahamował licznych i coraz 

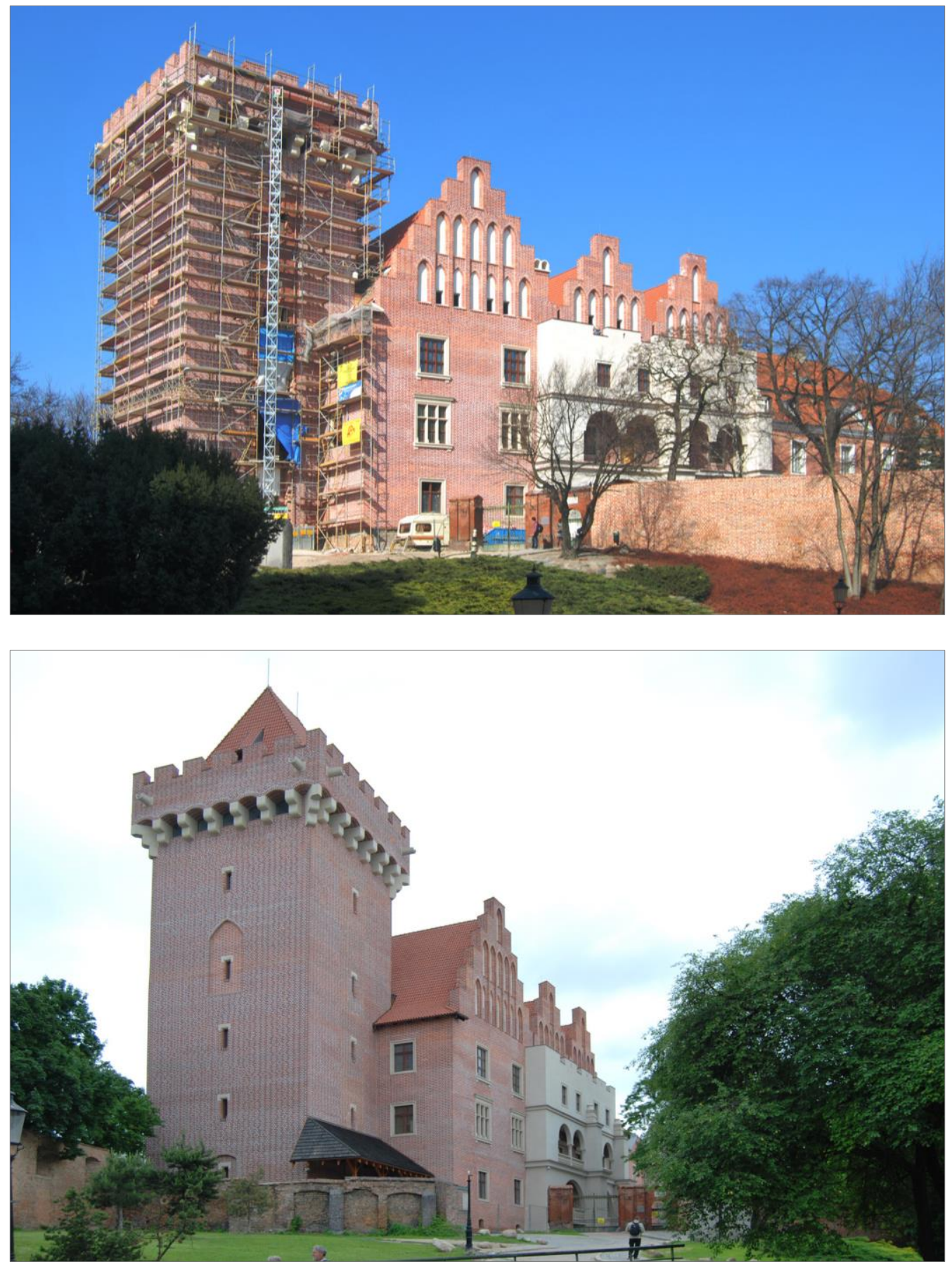

Fot. 4. Poznań, Zamek Przemysła, kolejne etapy odbudowy. Fot. J. Lewicki 2013-2015 
bardziej dziwacznych "rekonstrukcji”, ale wówczas powstało wiele stylizacji historycznych będących współczesnymi gargamelami naiwnie imitującymi przeszłość. W ostatnich latach metoda ta została zastosowana też do przekształcanej architektury powojennej. Fasady budynków wzniesionych w latach 60 . i 70. zaczęto zastępować nowymi elewacjami, które opracowano z zastosowaniem stylizowanych form historycznych. Jednak rażą one wytrawne oko swoją sztucznością i nieznajomością dawnych form oraz łamaniem stosowanych niegdyś zasad kształtowania historycznych porządków architektonicznych.

\section{Współczesna architektura na terenie zniszczonych zabytkowych miast}

O znaczeniu współczesnej architektury wznoszonej w sąsiedztwie zabytków i nowoczesnych stylizacji odbudowanych budowli pisano dawno. Już w 1946 roku historyk sztuki Ksawery Piwocki (Piwocki 1946: 53-59), dopuszczał nowe rozwiązanie „zagadnień urbanistycznych”, jak i „konieczność przystosowania odbudowywanego obiektu do potrzeb codziennych" (Piwocki 1946: 53-59). Podobnie wówczas myślał Antoni Karczewski, który podkreślał konieczność przywrócenia zabytków do „praktycznej użyteczności” (Karczewski 1946: 193-197). Rok później w 1947 roku przyjęte metody nowoczesnej odbudowy zostały uznane przez P. Biegańskiego jako zgodne $z$ tendencjami światowymi i „biegnące po nowoczesnej linii" (Biegański 1947: 129-137). Wprowadzanie nowych rozwiązań komunikacyjnych, rozluźnienie zabudowy i wprowadzanie nowych funkcji stało się nie tylko w pełni dopuszczalne, ale i zostało uznane, jako niezbędny zabieg wykonywany $\mathrm{w}$ procesie odbudowy. Dowodem zachowania autentyzmu historycznego miasta stało się utrzymanie jego funkcji połączonej z odbudową najważniejszych zabytków w formie zmienionej i dostosowanej do współczesnych potrzeb. Najbardziej autentyczny stał się przekaz nowo ukształtowanego historycznego zespołu miejskiego z wprowadzonymi nowymi funkcjami, współczesnymi rozwiązaniami komunikacyjnymi, rozluźnioną zabudową oraz "odbudowanymi zabytkami", które otrzymywały nową formę będącą swobodną kreacją historyczną. Bezwzględna wierność $\mathrm{w}$ stosunku do stanu sprzed zniszczenia była stosowana sporadycznie i tylko $\mathrm{w}$ odniesieniu do najcenniejszych zabytków, których forma zewnętrzna i rozwiązanie planu także ulegało zmianie - np. modyfikacja fragmentów bryły i elewacji najcenniejszych kamienic staromiejskich czy kościołów w Warszawie, odbudowywanych zabytków Poznania, katedr w Gnieźnie i Poznaniu czy Zamku Królewskiego w Warszawie. Dopuszczono wznoszenie licznych budowli o współczesnej formie na terenie zniszczonych zabytkowych miast jak i w ich sąsiedztwie. Podobny sposób postępowania stosowano na wielką skalę nie tylko 
w okresie PRL, ale i po 1989 roku. Rozpoczęła je kontynuowana i znacznie rozwinięta tzw. retrowersja zabudowy zniszczonych miast, w wyniku której na terenie opustoszałych historycznych centrów miast powstały nowe realizacje, które operowały współczesnym językiem postmodernistycznym form. Tę metodę zapoczątkowała odbudowa Elbląga i była ona kontynuowana i zintensyfikowana po 1989 roku (Lubocka-Hoffmann 1998). Później podobne prace objęły miasta na terenie ziem zachodnich i północnych, w tym liczne zniszczone wojną miasta na pograniczu polsko-niemieckim (Lubocka-Hoffmann 2004). Nowo wzniesiona zabudowa operująca historycznymi stylizacjami stała się ważnym elementem kształtującym nowy obraz tych miast. Obok retrowersji w centrach dużych historycznych ośrodków miejskich wznoszono nowoczesne budowle, które stanowiły ważny akcent urbanistyczny i architektoniczny. Najwięcej tego typu realizacji powstało we Wrocławiu, ale i w innych dużych miastach - w Warszawie, Gdańsku, Poznaniu, Szczecinie i w pozostałych ośrodkach. Wzniesione wówczas nowoczesne budynki urzędów, siedzib banków, różnych instytucji, ale także apartamentowce i typowe budynki mieszkalne. Nowe budowle stały się synonimem nowoczesności i modernizacji i były namacalnym przykładem rozwoju i dobrej sytuacji ekonomicznej tych miast. W dużym stopniu ukształtowały one współczesny obraz zabytkowych miast i stały się dowodem osiągnięć przemian po 1989 roku.

\section{Stosunek do przeszłości}

Po 1989 roku nastąpiła też znacząca zmiana stosunku do przeszłości. Objęła ona wiele dziedzin. Najbardziej widocznym elementem przemian była zmiana stosunku do obcego dziedzictwa oraz uznanie i upowszechnianie wielokulturowości. Proces ten rozpoczął się w 1989 roku i następował powoli. W latach 90. XX wieku nadal istniały sprawy sporne i konflikty wokół wielonarodowych zabytków. Najbardziej znanym przykładem była przebudowa przemyskiego kościoła karmelitów i samowolne usunięcie cennych elementów pochodzących z czasów użytkowania kościoła jako grekokatolickiej katedry (rozbiórka kopuły) (Lewicki 2013: 216-218). Pojawiały się też konflikty wokół opuszczonych niemieckich cmentarzy. W późniejszych latach zabytki niemieckie, żydowskie czy ukraińskie powoli przestawały dzielić i stopniowo zaczynały łączyć lokalnych mieszkańców. Były to protestanckie kościoły, grekokatolickie i prawosławne cerkwie, czy liczne cmentarze znajdujące się wśród jednolitych narodowo społeczności, które zostały zaakceptowane przez wszystkie grupy etniczne i przede wszystkim przez większość społeczeństwa. Stały się one w opinii lokalnych społeczności „wspólnym dziedzictwem". Ich obcość kulturowa obecnie nie tylko nie stanowi problemu, ale została "oswojona” przez okolicznych mieszkańców. Rozpoczęto planową i długofalową 
ochronę oraz konserwację tych zabytków (Kowalski 1995: 15-23), która przestała być fasadowym nakazem jak $w$ okresie PRL. Ochrona i konserwacja wspólnego dziedzictwa stała się przedsięwzięciem realizowanym z pełnym przekonaniem przy oddolnym poparciu społecznym. Obce zabytki stały się uznane za własne przez mieszkające obok różne społeczności i grupy etniczne. Są one bez problemów reklamowane i promowane. Dorobek różnych społeczeństw obecnie łączy niegdyś obce, a nawet wrogie społeczności. Dziedzictwo niemieckie czy żydowskie przestało być problemem i elementem przypominania o groźbie "powrotu Niemców czy Żydów". Sytuacja wielonarodowych zabytków po 1989 roku w Polsce znacznie się poprawiła i często odbiega od losów wielonarodowych zabytków w innych krajach. Przykładem są liczne zabytki z różnych obszarów niegdyś wielonarodowych - węgierskie na Słowacji, węgierskie w Rumunii, niemieckie w Czechach, rosyjskie na Ukrainie czy polskie na Białorusi lub Litwie, które w najlepszym przypadku nadal są przebudowywane, a ich okoliczności powstania reinterpretowane lub też skazane na zapomnienie i powolne niszczenie (Lewicki 2013: 209-216). Wydawało się, że dzisiejsze czasy odrzuciły tego typu sytuacje, ale tak się nie stało. Globalizujący się świat i niejednokrotnie sąsiadujące kraje są dziś miejscem przeciwstawnych podstaw wobec zabytków. Jedynym elementem zapobiegającym podobnym sytuacjom są wzajemne powiązania między narodami i wdrożone procedury demokratycznego zarządzania, które obejmują także kulturę i zabytki.

Przeciwstawnym nurtem, który jest coraz bardziej widoczny jest zapomnienie i zaniedbanie dawnego dziedzictwa. Jest ono efektem urynkowienia gospodarki i coraz większej obojętności zmaterializowanego społeczeństwa do przeszłości. Spotyka to szczególnie zabytki opuszczone i porzucone przez dawnych użytkowników i będące jedynym świadectwem nieistniejących społeczności czy kultur np. znikających ostatnich pamiątek po osadnikach niemieckich i holenderskich (zwanych $\mathrm{w}$ Polsce olędrami lub menonitami) czy niemieckich $\mathrm{w}$ Czechach lub w Polsce. Najczęściej opuszczane są jednak liczne zabytki żydowskie, pozostałe na terenach, gdzie mieszkała liczna ludność żydowska, którą wymordowano podczas II Wojny Światowej. Dotyczy to głównie domów, niewielkich miejsc kultu czy cmentarzy, bo wielkie synagogi znajdujące się w centrach miast zazwyczaj zostały zrewaloryzowane i mają świadczyć, że pozostałe zabytki żydowskie także są otoczone opieką. Podobny problem dotyczy budowli, które utraciły swoje pierwotne funkcje - budowli przemysłowych - dawnych fabryk, młynów, zabudowy kolejowej itp. Porzucone i opuszczone stały się nie tylko problemem dla otaczających mieszkańców, a tylko znalezienie nowej funkcji stanowiło jedyny ratunek przed ich zupełną ruiną i rozbiórką. Ocaleniem dla nich jest jedynie zainteresowanie społeczeństwa, a obojętność i zapomnienie wobec tych artefaktów przeszłości skazuje je na zagładę. 
Zupełnie nowym nurtem dotyczącym stosunku do przeszłości jest jej komercjalizacja łącząca się z sentymentalnym oswojeniem i współczesną kreacją zabytków. Dawne dziedzictwo stał się elementem komercyjnego wykorzystania i czerpania z niego możliwie największych dochodów. Jest to jednak zupełnie inny problem i będzie on coraz bardziej widoczny w globalizującym się świecie

\section{Ocena podejmowanych działań}

Na początku lat 90. ochrona zabytków i podejmowane wcześniej działania doczekały się podsumowań i ocen. Autorami analiz było kilku wybitnych historyków sztuki. Opublikowane prace Teresy Jakimowicz, Adama Miłobędzkiego i Andrzeja Tomaszewskiego w zadziwiająco zgodny i krytyczny sposób przedstawiały tendencje $\mathrm{w}$ polskiej ochronie zabytków. Odbiegały one od dotychczasowych syntez (Zachwatowicz 1965: 24-106; Rymaszewski 1992: 51-154; Rymaszewski 2005: 101-176), które w sposób niemal hagiograficzny prezentowały dokonane osiągnięcia $\mathrm{w}$ dziedzinie konserwacji i ochrony zabytków epoki PRL, podczas kiedy w tych latach tylko jedna osoba potrafiła otwarcie napisać o niekorzystnych ówczesnych zjawiskach i dokonać krytycznego podsumowania (Chrzanowski 1966: 914-932). W opublikowanych u schyłku PRL pracach opisano tendencje panujące $\mathrm{w}$ ochronie zabytków, elementy doktrynalne, jak i szczegółowo przeanalizowano w nich problem rekonstrukcji. Adam Miłobędzki podkreślił, że ochrona zabytków od połowy XX wieku jest nieustannie powiązana z władzą i nadal kultywuje neoromantyczny kult rekonstrukcji. Podkreślił rolę kultu rocznic, który jest przejawem kolejnych manipulacji związanych z zabytkami oraz postępującą manipulację i sztuczność kultu zabytków, który stracił kontakt ze swoimi najliczniejszymi odbiorcami, jakimi byli przedstawiciele warstwy średniej i odbiorcy kultury wysokiej (Miłobędzki 1997b: 97-101). Miłobędzki podkreślał też postępujący kryzys "polskiej ochrony zabytków” będący efektem degradacji więzi społecznych i związków z najbliższym otoczeniem. Całe społeczeństwo jak i lokalne społeczności oderwały się od "swojego" dziedzictwa, a zabytki stały się "znakami zabytków" (Miłobędzki: 19-22). Na powiązanie polityki i ochrony zabytków oraz na podporządkowanie różnych przedsięwzięć konserwatorskich doraźnym celom politycznym zwracał także uwagę A. Tomaszewski (Tomaszewski 1995: 423). W podobnym duchu wypowiadała się Teresa Jakimowicz, która podkreślała powiązania ochrony zabytków z bieżącymi działaniami politycznymi. Uznała, że pozbawione podstaw „rekonstrukcje” były jednym z z przejawów upadku polskiej ochrony zabytków. Jakimowicz podkreśliła, że „stan świadomości społecznej na temat zabytków jest równie zły, co wynika z wieloletniej deformacji problemu przez urzędową propagandę i z tworzenia mitów o jego doskonałości" (Jakimowicz 1994: 428). 
Te krytyczne oceny były próbą odmiennego spojrzenia na ochronę zabytków w PRL, ale wskazały one dalsze trwanie występujących wówczas tendencji. Napisane wówczas teksty $\mathrm{w}$ ważnych periodykach naukowych nie tylko nie doczekały się dalszej dyskusji, ale nie są przywoływane w piśmiennictwie z ochrony zabytków, które tworzyli konserwatorzy. Wymienione opracowania zostały nie tylko przemilczane, a dokonana ocena okazała się bardzo niewygodna. Współczesna rzeczywistość dowiodła słuszności ocen Teresy Jakimowicz, Adama Miłobędzkiego i Andrzeja Tomaszewskiego i dalszego trwania opisanych przez nich zjawisk.

\section{Podsumowanie}

Lata po 1989 roku stanowiły kontynuację epoki poprzedniej. Nadal kontynuowano wszystkie zjawiska z okresu PRL - liczne swobodne rekonstrukcje i odbudowy zabytków, choć zakres działań był tak różny, że często trudno jest zakwalifikować, czym były motywowane wykonane prace i jak je precyzyjnie określić. Wiele z nich było swobodnymi stylizacjami historycznymi, a odtwarzane zabytki nadal tworzono tak, aby były „piękniejsze niż kiedykolwiek”. Jednak w okresie PRL towarzyszyła temu refleksja teoretyczna z wysuwanymi nowymi argumentami i spostrzeżeniami, a ostatnie lata nie posługiwały się nowymi tezami i uzasadnieniami. Przykładem jest jedna z najbardziej widocznych realizacji ostatnich lat - odbudowa poznańskiego zamku, której poświęcono szereg publikacji i książek (Barełkowski 2003; Dolczewski 2004; Rola 2004; Zamek książąt 2004; Zamek królewski 2004; Barełkowski 2014), jednak przytaczane argumenty nie uzasadniają budowę "zabytku” w zrealizowanej formie. Można więc mówić o długim trwaniu wypracowanych metod i sposobów działania w dziedzinie ochrony zabytków, które nadal są stosowanie $\mathrm{w}$ nowej rzeczywistości społecznej i w zmienionych warunkach ustrojowych.

Nowym zjawiskiem z ostatnich lat była rzeczywista akceptacja wielonarodowego dziedzictwa i szereg oddolnych działań na rzecz jego ochrony i konserwacji. Także powstało bardzo wiele obiektywnych opracowań na jego temat. Okres po upadku PRL przyniósł także nowe wyzwania - najważniejszym był zmiana użytkowników wielu budowli, a w konsekwencji ich opuszczenie i konieczność znalezienia nowej funkcji. Ogromna liczba dawnych fabryk, młynów, magazynów, budowli przemysłowych i kolejowych została zrujnowana i rozebrana. Wiele trwa w stanie opuszczenia i coraz większej ruiny. Tylko nieliczne te zabytkowe budowle zostały adaptowane, co zawsze było szeroko opisywane. Sugeruje to, że całe dawne dziedzictwo poprzemysłowe i kolejowe zostało ocalone, a dotyczy to niestety niewielkiej liczby zabytkowych fabryk, młynów i budowli kolejowych. Innym wielkim wyzwaniem była globalizacja i urynkowienie, które objęła także 
zabytki. Było to zupełnie nowe zjawisko, które dziś stało się najważniejszym czynnikiem kształtującym stosunek do zabytków. Ale to już raczej syndrom nowych czasów i temat na oddzielne rozważania.

\section{BIBLIOGRAFIA}

Arszyński, Marian. Idea - Pamięć - Troska. Rola zabytków w przestrzeni społecznej i formy działania na rzecz ich zachowania od starożytności do połowy XX wieku. Malbork: Muzeum Zamkowe, 2007.

Barełkowski, Robert. Restytucja Zamku Królewskiego w Poznaniu. Poznań: Politechnika Poznańska, 2003.

Barełkowski, Robert. Restytucja zamku królewskiego w Poznaniu; Zamek królewski w Poznaniu. Historia i restytucja. Komitet odbudowy zamku królewskiego w Poznaniu. Poznań: Ośrodek Wydawnictw Naukowych, 2003.

Biegański, Piotr. „Konserwacja zespołów miejskich”. Biuletyn Historii Sztuki i Kultury, 9 (1947), nr 1/2, czerwiec, S. 129-137.

Biegański, Piotr. Pałac Staszica - Siedziba Towarzystwa Naukowego Warszawskiego. Warszawa: Nakładem TNW, 1951.

Dolczewski, Zygmunt. Tajemnice Zamku Królewskiego w Poznaniu. Poznań: Wydawnictwo Towarzystwa Opieki nad Zabytkami, 2004.

Chrzanowski, Tadeusz. „Konserwacja zabytków w Polsce po II wojnie światowej”. Znak 7-8 (145-146), R. XVIII (1966). S. 914-932.

Falser, Michael. „Die Erfindung einer Tradition namens Rekonstruktion oder Die Polemik der Zwischenzeilen. Rezension der Münchener Ausstellung: Geschichte der Rekonstruktion - Konstruktion der Geschichte“. Denkmalpflege statt Attrappenkult. Gegen die Rekonstruktion von Baudenkmälern - eine Anthologie (Bauweltfundamente 146). Adrian von Buttlar u. a. (Hrsg.). Basel/Berlin, 2010. S. 205-218.

Frycz, Jerzy. Konserwacja i konserwacja zabytków architektury w Polsce w latach 1795-1918. Warszawa: Państwowe Wydawnictwo Naukowe, 1975.

Jakimowicz, Teresa. „»Polska Szkoła Konserwatorska« - mit czy rzeczywistość”. Kwartalnik Urbanistyki i Architektury 3-4, 38 (1994). S. 421-428.

Karczewski, Antoni J. M. „Narodowy program konserwacji zabytków”. Biuletyn Historii Sztuki i Kultury 3/4, 8 (1946). S. 193-197.

Kowalski, Wojciech. "Międzynarodowo-prawne implikacje ochrony dziedzictwa kulturowego na zachodnich i północnych ziemiach Polski". Ochrona dziedzictwa kulturowego zachodnich i pótnocnych ziem Polski. Red. Jerzy Kowalczyk. Warszawa: Stowarzyszenie Konserwatorów Zabytków, Polski Komitet ICOMOS, 1995. S. 15-23.

Lalewicz, Marian: „»Pałac Staszica« w Warszawie Zarys historyi budowy, przebudowy i odbudowy. Towarzystwo Naukowe Warszawskie. Warszawa: Towarzystwo Naukowe Warszawskie, 1932, S. 34-58.

Lewicki, Jakub. „Konflikt o zabytki i miejsca pamięci czyli o nowo-starym postrzeganiu przeszłości w Europie Środkowej i Wschodniej po 1989 roku". Porównania 13 (2013). S. 216-218.

Lubocka-Hoffmann, Maria. Elbląg Stare Miasto. Elbląg: Wojewódzki Urząd Ochrony Zabytków Delegatura w Elblągu, 1998.

Lubocka-Hoffmann, Maria. Miasta historyczne zachodniej i pótnocnej Polski. Zniszczenia i programy odbudowy. Elbląg-Bydgoszcz: Wojewódzki Urząd Ochrony Zabytków Delegatura w Elblągu. Oficyna Wydawnicza Excalibur w Bydgoszczy, 2004. 
Miłobędzki, Adam. „Architektura zabytkowa w kadrze współczesnej świadomości historycznej”. Historia a system. Red. Maria Poprzęcka. Warszawa: Arx Regia Ośrodek Wydawniczy Zamku Królewskiego, 1997. S. 97-101.

Miłobędzki, Adam. „Polska szkoła konserwatorska”. Arka 1(49) (1994). S. 131-141.

Miłobędzki, Adam. „»Polska szkoła konserwatorska« - mit czy rzeczywistość”. Ars sine scientia nihil est. Księga ofiarowana Profesorowi Zygmuntowi Świechowskiemu. Warszawa: Dom Wydawniczy ARS, 1997. S. 160-165.

Miłobędzki, Adam. „Polska szkoła konserwacji?” Adam Miłobędzki, Krzysztof Chmielewski, Jarosław Krawczyk. Kazimierz odnowiony. Jego zabytki i krajobraz kulturowy. Warszawa: Muzeum pałac w Wilanowie, 2003. S. 19-22.

Miłobędzki, Adam. „Zabytki, kultura, polityka”. Arche 9 (1995). S. 22-25.

Nerdinger, Winfried (Hrsg.). Geschichte der Rekonstruktion - Konstruktion der Geschichte. München 2010.

Piwocki, Ksawery. „Uwagi o odbudowie zabytków”. Biuletyn Historii Sztuki i Kultury, 1-2(8) (1946). S. 53-59.

Rola, Zygmunt. Tajemnice Zamku Przemysława. Poznań: Wydawnictwo Kurpisz, 2004

Rymaszewski, Bogdan. Klucze ochrony zabytków w Polsce. Warszawa: Ośrodek Dokumentacji Zabytków, 1992.

Rymaszewski, Bogdan. Polska ochrona zabytków. Warszawa: Wydawnictwo Naukowe „Scholar”, 2005.

Rymaszewski, Bohdan. „Wstęp”. Zabytki urbanistyki i architektury. Odbudowa i konserwacja. Red. Wojciech Kalinowski. Warszawa: Arkady, 1986.

Tomaszewski, Andrzej. Polska szkoła konserwatorska. Mpis powielany. Warszawa, 1995.

Zachwatowicz, Jan. Ochrona Zabytków w Polsce. Warszawa: Wydawnictwo „Polonia”, 1965.

Zachwatowicz, Jan. „Program i zasady konserwacji zabytków”. Biuletyn Historii Sztuki i Kultury. T. 8, 1-2 (1948). S. 48.

Zamek ksiażąt, królów, starostów, Kronika Miasta Poznania 4 (2004). red. Jacek Wiesiołowski. Poznań: Wydawnictwo Miejskie, 2004.

Zamek królewski w Poznaniu. Zarys historii. Badania archeologiczne. Dziatania na rzecz restytucji. Oprac. red. H. Kondziela. Poznań: Wydawnictwo Komitetu Odbudowy Zamku Królewskiego w Poznaniu, 2004. 